\title{
Mapping and evaluation of the state of conservation of the vegetation in and surrounding the Chapada Diamantina National Park, NE Brazil
}

\author{
Roy Richard Funch ${ }^{1,3}$, Raymond Mervyn Harley² \& Ligia Silveira Funch ${ }^{1}$ \\ ${ }^{1}$ Departamento de Ciências Biológicas, Universidade Estadual de Feira de Santana - UEFS, \\ Av. Universitária, s/n, CEP 44031-460, Feira de Santana, Bahia, Brazil \\ ${ }^{2}$ Royal Botanic Gardens, Kew, Richmond, Surrey TW9 3AB, England, U.K \\ ${ }^{3}$ Corresponding author: Roy Richard Funch, e-mail: funchroy@yahoo.com
}

FUNCH, R.R., HARLEY, R.M. \& FUNCH, L.S. Mapping and evaluation of the state of conservation of the vegetation in and surrounding the Chapada Diamantina National Park, NE Brazil. Biota Neotrop. 9(2): http://www.biotaneotropica.org.br/v9n2/en/abstract?article+bn00209022009.

\begin{abstract}
The Chapada Diamantina National Park (CDNP) was created in the midst of a densely populated area, and significant sections of the reserve are still undergoing processes of natural regeneration after intensive diamond mining activities were initiated in the mid-1800's. An up-to-date vegetation map was needed in order to indicate the types and distribution of regional vegetation assemblages in an easily interpretable manner and at an appropriate planning scale that could be easily consulted by decision makers and other interested groups at all levels of conservation (and development) planning. A vegetation map of the Chapada Diamantina National Park, and the areas immediately surrounding it, was prepared that: 1) delimits, describes, and maps the regional vegetation assemblages; 2) provides an indication of the degree of conservation of the mapped vegetation; 3 ) develops this information in a format that facilitates continued updating and revision as more information becomes available, enabling the monitoring of the evolution of the Park lands, and; 4) presents this information in a manner that can be easily interpreted and used for planning, management and conservation purposes. The resulting vegetation map revealed intensive anthropogenic disturbances in forested, savanna, and semi-arid areas subjected to intensive agricultural use outside of the Park boundaries. The National Park lands are generally well preserved but burning has replaced formerly extensive forest areas with open sedge meadows. In spite of intensive modification of the regional vegetation, two well preserved areas with high priority for conservation efforts beyond the National Park limits were identified and characterized. The vegetation mapping of the park itself can aid in the preparation of its management plan and in the reformulation of the existing boundaries of that reserve.
\end{abstract}

Keywords: vegetation map, conservation planning, vegetation assemblages, forests.

FUNCH, R.R. HARLEY, R.M. \& FUNCH, L.S. Mapeamento e avaliação do estado de conservação da vegetação dentro e em torno do Parque Nacional da Chapada Diamantina, Nordeste do Brasil. Biota Neotrop. 9(2): http://www.biotaneotropica.org.br/v9n2/pt/abstract?article+bn00209022009.

Resumo: O Parque Nacional da Chapada Diamantina foi criado numa região densamente ocupada e grandes áreas dentro desta reserva ainda estão em vias de recuperação natural em decorrência da mineração de diamantes que começou em 1844. Um mapa atualizado da vegetação regional elaborado de maneira que facilite sua interpretação é imprescindível para orientar administradores e outros grupos interessados na preservação e desenvolvimento da região. Um mapa da vegetação do Parque Nacional da Chapada Diamantina e as áreas no seu entorno foi preparado: 1) delimitando e descrevendo os vários tipos de vegetação regional; 2) fornecendo indicações do grau de conservação da vegetação; 3) apresentando estas informações num formato que facilite sua revisão e atualização; e 4) apresentando estas informações de maneira fácil de interpretar, podendo ser usadas para fins de planejamento, manejo e conservação. O mapa demonstrou perturbações de origem antrópica nas áreas de floresta, cerrado e caatinga adjacentes ao Parque Nacional. As terras dentro da reserva são, em geral, bem preservadas, demonstrando reduzidas alterações antrópicas diretas, embora freqüentes incêndios tenham transformado extensivas áreas de floresta em campos abertos. Apesar das modificações da vegetação regional, existem duas áreas relativamente bem preservadas fora dos limites do Parque Nacional que possuem alta prioridade para ações conservacionistas. O mapa da vegetação apresentado pode auxiliar na elaboração do Plano de Manejo da reserva e na reformulação futura dos seus limites.

Palavras-chave: mapa de vegetação, conservação, planejamento, florestas. 


\section{Introduction}

The Chapada Diamantina National Park (CDNP) is the largest conservation area in Brazil outside of the Amazon region $\left(1,520 \mathrm{~km}^{2}\right)$, and one of the most popular sites for eco-tourism in northeastern Brazil. The park was created in the midst of a densely populated area and significant sections of the reserve are still undergoing processes of natural regeneration after intensive diamond mining activities were initiated in the mid-1800's. The non-montane areas adjacent to the Park have experienced accelerated development in the past two decades due to the opening of new heavily mechanized agricultural areas, the settling of landless farmers, and the expansion of tourism. These activities have resulted in altered patterns of land and water use, increasing human population densities, land clearing and deforestation, and the intensive use of agro-chemicals in the headwaters of the regionally important Paraguaçu River Basin. The 1,520 km² Chapada Diamantina National Park (CDNP), occupying approximately half of the entire Sincorá Range, has to some extent counterbalanced this regional growth by defining significant areas of mountain landscape as (legally) immune to anthropogenic alterations. Although it was founded more than 20 years ago (1985), the National Park still suffers from budget restrictions, limited staff, and few planning tools. The publication of the first management plan for the park is being programmed, and its success as an operational document will depend on the availability of detailed and up-to-date information concerning the ecosystems that compose the reserve, their conservation status, the environmental threats they face, as well as the location and extent of human influences in the surrounding region. Additionally, this same information will be used to orient the National Park System in its acquisition of new areas contiguous to the existing reserve.

As such, vegetation maps are needed to indicate the types and distribution of regional vegetation assemblages in an easily interpretable manner and at an appropriate planning scale so as to be easily consulted by decision makers and other interested groups at all levels of conservation (and development) planning.

The vegetation of the Chapada Diamantina National Park was mapped in a non-digital format in 1994, without the aid of satellite images or GIS (CPRM 1994), and employing out-dated aerial photographs (1974), and a vegetation classification system not suitable for easy interpretation by non-specialists.

As such, the objectives of this study were to: 1 ) delimit, describe, and map the vegetation assemblages of the Chapada Diamantina National Park (CDNP) and the areas immediately surrounding it; 2) provide an indication of the degree of preservation of the mapped vegetation; 3 ) capture this information in a format that facilitates continued updating and revision as more information becomes available, enabling the monitoring of the evolution of the Park lands; 4) identify priority areas for protection and preservation, and; 5) present this information in a manner that can be easily interpreted and used for planning, management, and conservation purposes.

\section{Materials and Methods}

\section{Description of the area}

The study area is located in the northern sector of the Espinhaço Mountain Chain (in the states of Minas Gerais and Bahia) that lies slightly inland along the central Atlantic Coast of Brazil, and included the entire legal limits of the Chapada Diamantina National Park $\left(1,520 \mathrm{~km}^{2}\right)$ as well as regions up to $10 \mathrm{~km}$ beyond its boundaries, in the northern sector of the Sincorá Range (approximately $12^{\circ} 11^{\prime}-13^{\circ} 32^{\prime} \mathrm{S}$ and $40^{\circ} 53^{\prime}-41^{\circ} 42^{\prime} \mathrm{W}$ ) (Figure 1).
Almost the entire central section of the mapping region (the Sincorá Range and the Chapada Diamantina National Park) (Figure 2) is composed of extremely old (1.7+ b.y.) Precambrian sandstones, conglomerates, and quartzites, and is part of the ancient Brazilian Shield (CPRM 1994) with elevations averaging about $900 \mathrm{~m}$ above sea level and peaks up to $1,700 \mathrm{~m}$. Soils are limited to sandy, usually thin, dystrophic neosols, with exposed rock surfaces covering a high percentage of the Sincorá mountain range (CPRM 1994). The regional climate is seasonally humid and mesothermic, with mild, wet summers and cool, dry winters. Average monthly temperatures range from about 18 to $22^{\circ} \mathrm{C}$, although these vary considerably with altitude. Freezing temperatures have never been reported in the region and summer temperatures rarely pass $35^{\circ} \mathrm{C}$. The period of heaviest rainfall is normally from November to March, and the dry season usually lasts from July to early November, although periods of prolonged drought are not uncommon. The average yearly rainfall in the Sincorá Range is $1,192 \mathrm{~mm}$, although total precipitation is extremely variable (e.g. $357 \mathrm{~mm}$ in 1,993 and 1,721 $\mathrm{mm}$ in 1989), as is its distribution throughout the year (Harley, 1995; Seixas, 2004).

The eastern sector of the mapping region is a generally flat but deeply dissected plain, covered principally by deep dystrophic latosols (Nolasco et al. 2008) (Figure 2). Elevations there range from approximately $400 \mathrm{~m}$ to $600 \mathrm{~m}$ a.s.l., with an annual average rainfall at the extreme eastern edge of the mapping area of $580 \mathrm{~mm}$ (Seixas, 2004). The area is drained exclusively by tributaries of the Paraguaçu River. The principal vegetation types and landscape features encountered in this region are: 1) sub-montane to montane semi-deciduous seasonal forests on deep latosols, and; 2) wetlands.

The south-western sector of the study area is a large, relatively flat plain (although more dissected in the north) at approximately $900 \mathrm{~m}$ a.s.l., covered principally by dystrophic argisols (moderately deep, well-drained soils) and latosols over deep Tertiary-Quaternary deposits (Rocha et al. 2005) (Figure 2). The annual average rainfall at the extreme western edge of the mapping area is $797 \mathrm{~mm}$ (Seixas, 2004). The principal vegetation type encountered in this region is cerrado (savannas).

The northwestern sector of the study area presents an irregular landscape of low mountains and deeply dissected plains (Figure 2). The area is drained exclusively by tributaries of the Paraguaçu River. The soils in the southern half of this sector are thin and dystrophic sandy neosols. The average rainfall in the region is $797 \mathrm{~mm}$ (Seixas, 2004). The principal vegetation type encountered in this region is caatinga (semi-arid vegetation) (Queiroz et al. 2005).

Additionally, transition/mosaic areas (where two or more distinct vegetation types come into contact), anthropogenic landscapes, and areas with alluvial sands are found in all map sectors. All vegetation types and landscapes will be discussed in more detail in the following sections.

\section{Imagery and image interpretation}

Two Landsat 7 ETM images (path 217 / row 69; 11 Oct. 2002 and 12 Aug. 2002) were necessary to achieve minimal cloud cover in complimentary regions of the study area. Both images were acquired in the dry season of the same year. The two digital images were georeferenced to Universal Transverse Mercator (UTM) map coordinates using common control points extracted from topographic maps at a scale of 1:100,000 (datum Córrego Alegre) (SUDENE 1977). More than 25 band combinations were tested in an attempt to define the best mix for distinguishing the various vegetation types, bare natural surfaces, and anthropogenic features (farm plots, roads, fence lines, etc.). Bands 7, 5 and 3 were chosen for the final vegetation map as they were judged ideal for visually distinguishing natural and manmade features, while closely approximating natural landscape 


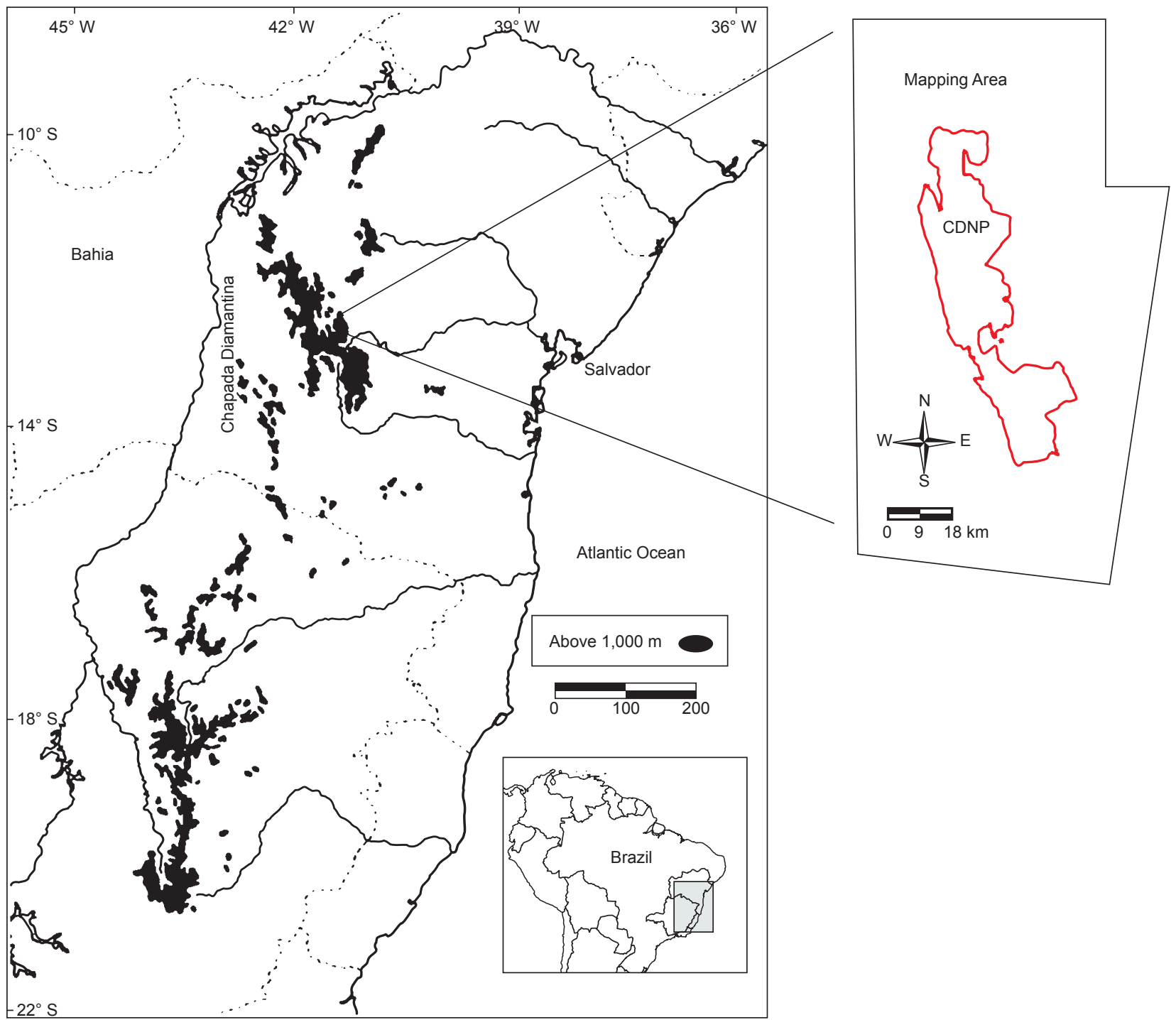

Figure 1. Map showing the location of the Espinhaço Mountain Range, Brazil, indicating the vegetation mapping area as well as the Chapada Diamantina National Park (CDNP), Bahia State, Brazil.

Figura 1. Mapa de localização da Serra do Espinhaço, indicando as áreas de vegetação que foram mapeadas e o contorno do Parque Nacional da Chapada Diamantina (PARNA-CD), Bahia, Brasil.

tones. No computer-aided vegetation classifications were performed and all identifications of the vegetation/ecological sites were based on an intimate personal knowledge of the landscape and innumerous field excursions to verify in loco the vegetation status of all areas mapped. Additionally, the highest local elevations were scaled and the landscape features visible below these elevated points were then traced onto 1:60,000 aerial photographs of the region (1974) or directly onto printed reproductions of the satellite images (see Kingston $\&$ Waldren 2003). All field data was subsequently transferred to the digitalized satellite images in an ARCVIEW 3.2 format.

Field visits involved inspection of the vegetation on the ground, collection of plant material, basic soil classification, and geo-referencing the localities with a hand held GPS. Field-confirmation of these sites was necessary for the CDNP sits at contact zones where widespread and distinct vegetation types (campo rupestre, forest, caatinga, cerrado, and sedge meadows) often form transition or mosaic zones influenced by local factors such as soils, altitude, slope, and aspect. Additionally, even apparently uniform stands of vegetation, such as the sub-montane forests on extensive latosol plains, have almost invariably been subjected to local anthropogenic influences (such as harvesting and burning) that could not be easily determined from the satellite images themselves.

\section{Vegetation sampling}

Rapid Ecological Assessment (REA) techniques (Sayre et al. 2000) were employed in surveying 33 different sites among the various vegetation types encountered in the study area (indicated on Figure 2). The REA technique generally employs circular plots to facilitate geo-referencing, and a radius of $15 \mathrm{~m}\left(1,256 \mathrm{~m}^{2}\right)$ was used to characterize open formations (e.g. Pivello et al. 1999, Harley et al. 2005). However, it was found to be much more efficient to delimit and sample forest and shrub/forest formations using 30 sequential $2 \times 20 \mathrm{~m}$ plots $\left(1,200 \mathrm{~m}^{2}\right)$.

Collections were made between 1/2004 and 3/2005 in areas deemed important for characterizing the local vegetation, especially transition zones and vegetation types poorly sampled in previous surveys in the region. All material collected for identification was stored in the Herbarium of the Universidade Estadual de Feira de 
Funch, R.R. et al.

Vegetation of the Chapada Diamantina National Park and the sorrounding areas, Bahia state, Brazil

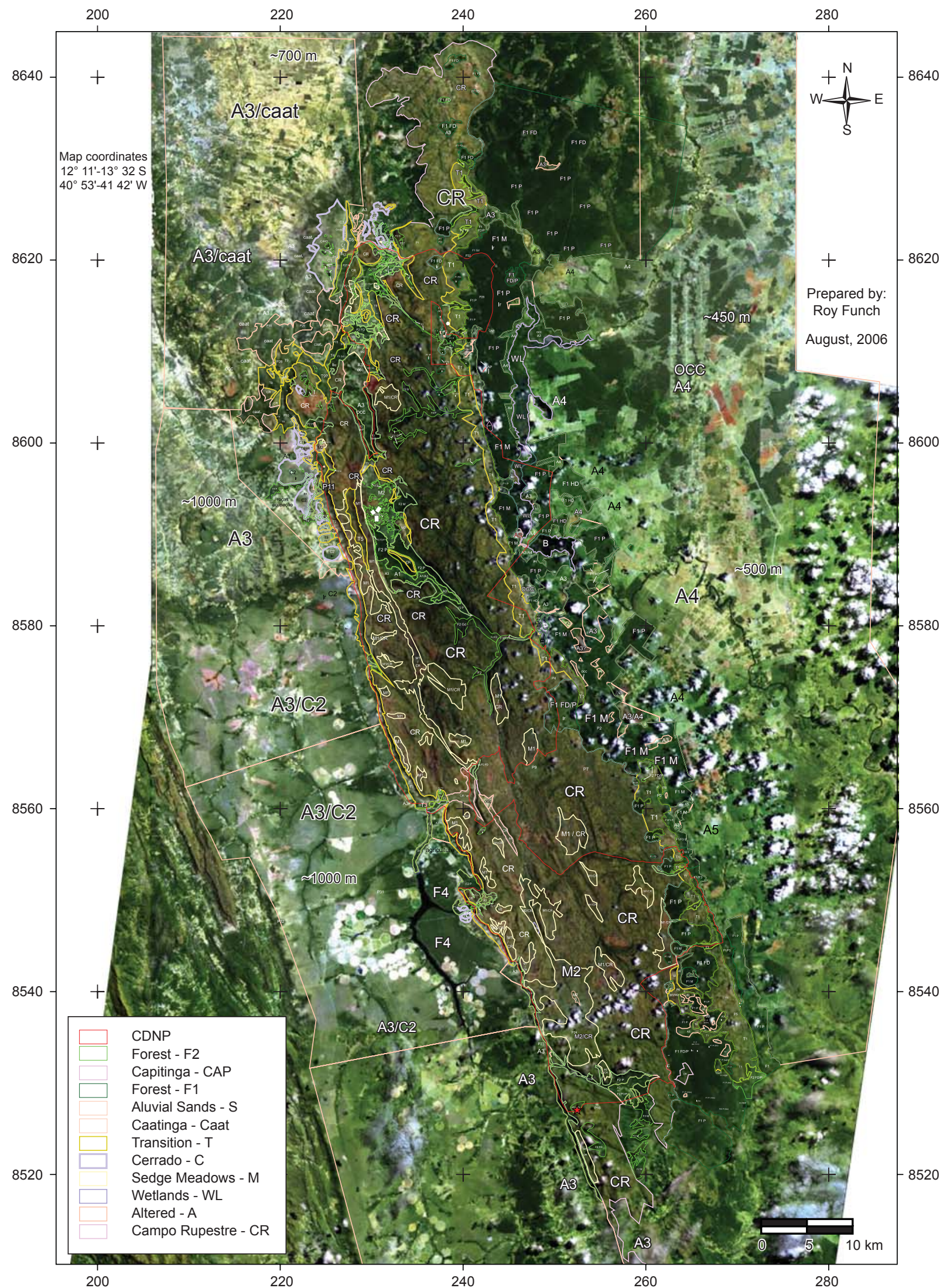

Figure 2. Vegetation map of the Chapada Diamantina National Park (CDNP) and surrounding areas, Bahia State, Brazil. A more detailed legend is presented in Table 1.

Figura 2. Mapa da vegetação do Parque Nacional da Chapada Diamantina e a área no seu entorno, Bahia, Brasil. Uma legenda mais detalhada é apresentada na Tabela 1. 
Santana (HUEFS), Bahia, Brazil. For purposes of this work, families were classified according to the APG II as presented by Souza \& Lorenzi (2005).

\section{Soils}

Pedological studies in Chapada Diamantina have revealed a mosaic of soil types reflecting the geological diversity of the region, climate, altitude, slope, exposure, hydrology, and vegetation (Jesus et al. 1985, CPRM 1994). A large percentage of the soils in the area mapped for vegetation were latosols, neosols (lithosols) and argisols (Rocha et al. 2005), all of which are consistently dystrophic and highly acidic.

Soils were further classified into very basic categories according to their color and, to some extent, their composition (predominance of sand or clay). Color was visually judged for fresh samples taken $>20 \mathrm{~cm}$ below the surface. Soil composition (sand or clay content) was subjectively tested using a simple technique of manipulating a small amount of moist soil.

\section{Vegetation types and ecological systems}

A diverse series of vegetation types were recognized, which are listed and briefly described below. Recognition was based partly on previous experience in the area, and further strengthened by observations made during the course of the project.

Campo rupestre (CR) is an open, low vegetation form found on nearly continuous rock surfaces in the mountain (usually above $800 \mathrm{~m}$ a.s.l.) primarily composed of sclerophyllous and evergreen shrubs or sub-shrubs and small trees that are highly specialized and adapted to conditions of low soil $\mathrm{pH}$ and low nutrient content, high insolation, and wide diurnal variations in temperature and humidity, with dew often providing much of their water requirements during periods of drought (Harley \& Simmons 1986) (Figure 3a).

Sandy sedge meadow $(\mathrm{M})$ vegetation is considered a variation of campo rupestre occurring on relatively flat landscapes in the mountains within the Sincorá Range on extremely thin, sandy, litholic neosols that are often saturated for fairly long periods of times during the rainy season (Figure $3 b$ ) and within high mountain valleys that have deep sandy soils but are subjected to frequent burning and are dominated by Cyperaceae, Graminae, Xyridaceae, and Eriocaulaceae (Harley 1995).

Sub-montane to montane semi-deciduous seasonal forests on deep latosols (Latosolic forests) (F1) occupy the entire eastern border of the Chapada Diamantina at altitudes between approximately 400-800 m (Funch et al. 2005). The landscape is generally a slightly undulating plain occasionally dissected by relatively narrow but often fairly deep "V" shaped river valleys. Rainfall is high at the foot of the Sincorá Range (approx. $1200 \mathrm{~mm} /$ year) but the region becomes progressively drier to the east and the forests there more deciduous.

Sub-montane to montane semi-deciduous seasonal to evergreen forests on litholic neosols (Montane lithosolic forests) (F2) cover the boulder-strewn and sometimes exceeding steep river valley slopes within the mountains of the Sincorá Range (Figure 3c). As the sandstone and conglomerate rocks that compose the mountains erode into loose sand and coarse gravel, they form dystrophic, rapidly drained, and (usually) thin soils (neosols) that become progressively drier at longer distances from the river (this effect can be modified depending on exposure, aspect, or the presence of natural seeps). Although predominantly evergreen, the montane lithosolic forests demonstrate a degree of deciduousness in the dry season (Funch et al. 2002).

Sub-montane to montane evergreen riparian forests (Riparian forests) (F3) are seasonal evergreen forests that follow river courses (Funch 2008) (Figure 3d).
Wetlands (W) are permanently inundated or boggy areas (Figure 3e).

Alluvial Sands (S) are regionally extensive alluvial sand deposits that are mostly geologically very recent and resulted from diamond mining activities in the mountains. These soils are of essentially pure sand, dystrophic, deep, rapidly drained, and frequently re-worked during seasonal flooding, resulting in an extremely sparse vegetation cover.

Transition/Mosaic Areas (T) - As a result of many interacting ecological factors related to altitude, exposure, slope, local geology, soil composition, soil depth, solar radiation, wind velocity, dew point, etc., the contact between two (or more) vegetation forms will result in a species-rich transition zone (often a mosaic), composed of elements from both communities.

Anthropogenic Zones (A) are areas that have been (or are presently) subjected to severe anthropogenic disruption of their natural vegetation cover.

Cerrado (Brazilian savannas) (C) vegetation is characterized, in general, by the presence of both a well defined ground and an arboreal layer (Figure $3 \mathrm{f}$ ). The ground layer is continuous in all but the pure forest physiognomy (called cerradão), and is composed principally of grasses, sedges, and numerous subshrubs (which can appear to be herbaceous but often possess a well-developed root systems with xylopods), acaulescent palms, and very few annual species. The arboreal layer is generally discontinuous and up to $10 \mathrm{~m}$ tall, with twisted branches, thick bark, and leaves that are rarely absent, large, and thick (Harley et al. 2005).

Caatinga (Caat) vegetation is highly xeromorphic with a predominance of profusely branched low trees and shrubs. The plants generally have small leaves, spines, thick bark, and a well-developed root system often with tubers (Queiroz et al. 2005) (Figure 3g). With few exceptions (such as palms and a few dicotyledons such as Zizyphus joazeiro Mart.), the plants are deciduous. Cacti are conspicuous, and there are many terrestrial bromeliads. Annual herbaceous plants flourish during the short rainy season, and in many regions vernal pools appear, although these are rarely seen in the present study area due to the very irregular topography near the Sincorá Range and the karst topography slightly further west. Caatinga occurs at low altitudes (below $500 \mathrm{~m}$ ) throughout most of its range, but flourishes at elevations between 700-1000 $\mathrm{m}$ in the study area in the rain shadow of the Sincorá Range (Queiroz et al. 2005).

Capitinga (CAP) - Small, scattered, and isolated areas of capitinga vegetation (up to a few hectares) exist throughout the region around the Sincorá Range growing on deep, extremely well-drained, fine sandy soils. Different from alluvial sand deposits, these sandy areas seem to be associated with the direct on-site weathering of friable sandstone outcrops and they are usually completely surrounded by latosol forest landscapes. The vegetation in these areas of capitinga is low and open with many shrubs, acaulescent palms, scattered and infrequent small trees and cacti; annual plants are rare and there is a high percentage of bare ground (Figure $3 \mathrm{~h}$ ). While similar in physiognomy to the coastal restinga vegetation and the dune areas bordering the São Francisco River (Rocha et al. 2004), capitinga is distinguishable from these other sites (L.S. Funch, unpublished data) as their species composition is quite different, there is no saline component to the environment, and the sands are not derived from wind or water transport and subsequent re-deposition. For these reasons, the local denomination for these sites has been retained

\section{Disturbance categories of forested areas}

Six disturbance categories were employed to describe the conservation status of the diverse forest formations: 
Funch, R.R. et al.
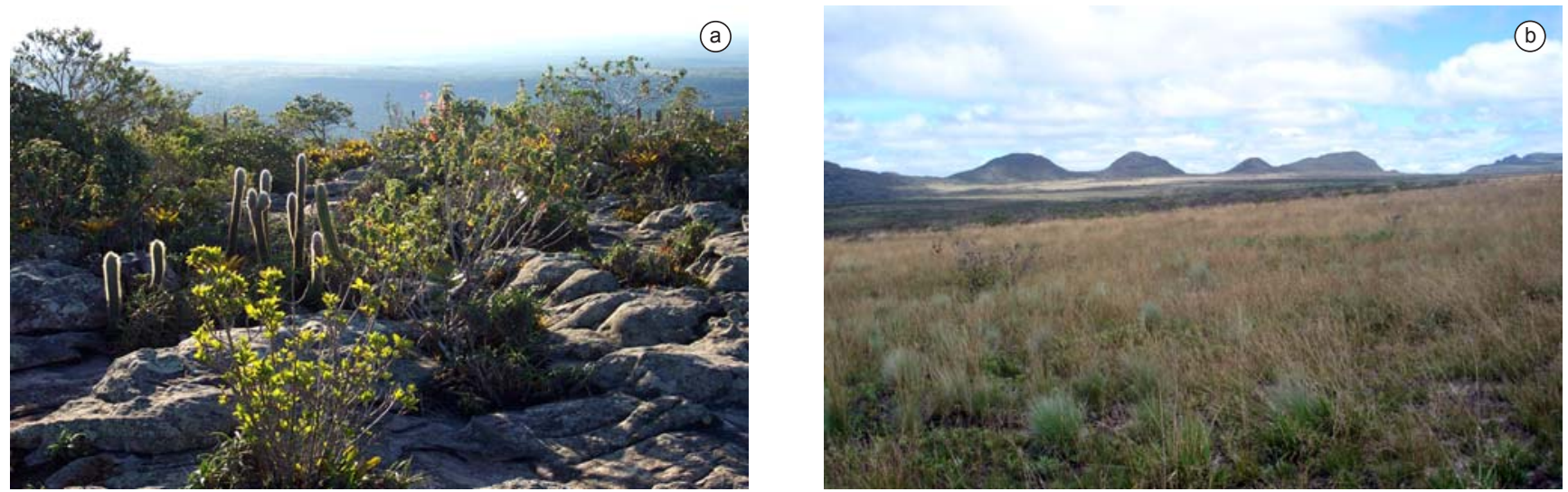

(C)
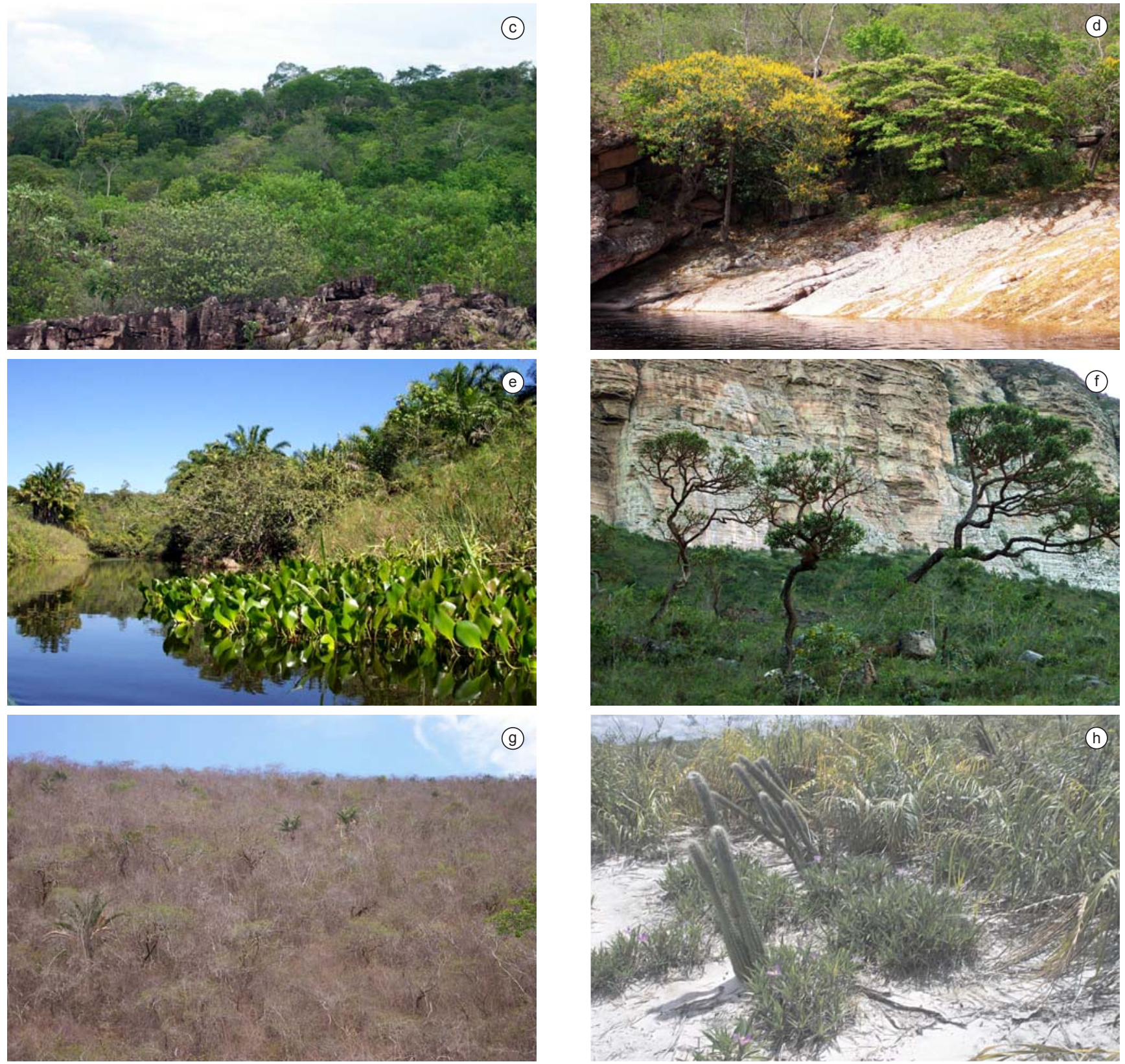

Figure 3. Major vegetation types and ecological systems within and surrounding the Chapada Diamantina National Park (CDNP), Bahia State, Brazil: a) Campo rupestre; b) Sandy sedge meadow; c) Lithosolic Forest; d) Riparian forest; e) Wetlands; f) Cerrado; g) Caatinga (during the dry season); h) Capitinga.

Figura 3. Os principais tipos de vegetação e ecossistemas dentro e em volta do Parque Nacional da Chapada Diamantina (PARNA-CD), Bahia, Brasil: a) Campo rupestre; b) Gerais; c) Floresta sobres solos litólicos; d) Floresta ciliar; e) Áreas alagadas; f) Cerrado; g) Caatinga (na estação de seca); h) Capitinga. 
Table 1. Vegetation map legend, listing and describing the vegetation and landscape classifications used for mapping the Chapada Diamantina National Park and bordering lands, Bahia, Brazil.

Tabela 1. Legenda do mapa de vegetação, relacionando e descrevendo a vegetação e a classificação da paisagem usada no mapeamento do Parque Nacional da Chapada Diamantina e nas áreas circunvizinhas, Bahia, Brasil.

\begin{tabular}{cc}
\hline $\begin{array}{c}\text { Map } \\
\text { designation }\end{array}$ & Vegetation or Landscape Classifications \\
\hline & Forests
\end{tabular}

F1 Sub-montane to montane semi-deciduous seasonal forests on deep latosols

F2 Sub-montane to montane semi-deciduous seasonal to evergreen forests on litholic neosols

F3 Sub-montane to montane evergreen riparian forests

F4 others

\section{Campo Rupestre}

CR Campo rupestre

\section{Sandy Sedge Meadows}

M1 Sandy Sedge Meadows on thin neosols

M2 Sandy Sedge Meadows on deep sandy soils, principally derived from burning

\section{Cerrado}

C1 Cerrado - campo limpo

C2 Cerrado - campo sujo

C3 Cerrado - campo cerrado

C4 Cerrado - cerrado "sensu stricto"

C5 Cerrado - cerradão

WL Wetlands

CAP Capitinga

\section{Transition/Mosaic Areas}

T1 Campo rupestre / Forest

T2 Campo rupestre / Sedge meadows (or Cerrado)

T3 Cerrado / Campo Rupestre

T4 Cerrado / (Campo Rupestre) / Caatinga

T5 Campo Rupestre + Sedge meadows + vestiges of fire-disturbed forest, in mosaic

T6 Forest / Cerrado

T7 Tall forest where more preserved; Cerrado / low forest with deciduous elements + Caatinga elements

T8 Shrub vegetation; highly disturbed (abandoned farm sites / fire damage)

T9 Campo rupestre / Caatinga

\begin{tabular}{cc}
\hline $\begin{array}{c}\text { Map } \\
\text { designation }\end{array}$ & Vegetation or Landscape Classifications \\
\hline
\end{tabular}

$\begin{array}{cl}\text { caat } & \text { Caatinga (dry-land) vegetation } \\ \mathrm{S} & \text { Alluvial Sands } \\ \text { OCC } & \text { Human occupation }\end{array}$

\section{Anthropogenic zones}

A1 Altered areas, but currently abandoned

A2 Areas altered by mechanical mining

A3 Agriculture

A4 Prepared pasture

A5 Other altered areas

\section{Disturbance categories of forested areas}

Good state of conservation; no signs of harvesting or fire damage; diverse mix of tree diameters and ample spacing of individuals; light underbrush

M Medium state of conservation; signs of selective harvesting; few large trees and close spacing of small trees; heavy underbrush

P Poor - damaged forests; visible signs of fire damage or harvesting; very dense spacing of small trees; heavy underbrush

FD Fire Damage - mature forest that has suffered recent heavy fire damage; many dead trees still standing; many live trees showing canopy damage; heavy underbrush

FD/P Fire Damage/Primary Forest - primary forest that has suffered sequential fire damage; signs of recent fire; very dense spacing of small trees; heavy underbrush

Heavily Disturbed - by non-fire factors (mechanical disturbances)

\section{Soils}

$1 \mathrm{r}$

$\operatorname{lrc}$

Latosols - red

Latosols - light red

lrb Latosols - red/brown

ly Latosols -yellow

lyc Latosols - light yellow

lw Latosols - white

ns Neosols

nw Neosols - white

$+\mathrm{cl} \quad$ With clay

ss Sandy

si Seasonally inundated 
Good (Gd) - good state of conservation; no signs of harvesting or fire damage; diverse mix of tree diameters and ample spacing of individuals; light underbrush.

Medium (M) - medium state of conservation; signs of selective harvesting; few large trees and close spacing of small trees; heavy underbrush.

Poor (P) - damaged forests; visible signs of fire damage or harvesting; very dense spacing of small trees; heavy underbrush.

Fire Damage (FD) - mature, primary forest that has visibly suffered recent heavy fire damage; many dead trees still standing; many live trees showing canopy damage; heavy underbrush.

Fire Damage/Poor Forest (FD/P) - already damaged forests (P) that have suffered additional burning; signs of recent fire; no large trees, very dense spacing of small trees; heavy underbrush.

Heavily Disturbed (HD) - by non-fire factors (mechanical disturbances)

\section{Results}

The vegetation map of the Chapada Diamantina National Park and neighboring areas is presented in Figure 2. As the vegetation map presented here is on a regional scale - and was principally designed to aid in regional planning, management and conservation - well-known and well-defined Brazilian ecosystem names were used (campo rupestre, caatinga, cerrado) (in addition to one truly regional sub-division, capitinga) to facilitate the understanding and use of the document. A detailed legend is presented in Table 1.

The Chapada Diamantina National Park $\left(1,524 \mathrm{~km}^{2}\right)$ (Figure 2) comprises 9 basic vegetation types/landscapes: 1) campo rupestre (63.4\% of the Park area); 2) sandy sedge meadows (13.4\%); 3) submontane to montane semi-deciduous seasonal to evergreen forests on litholic neosols (montane lithosolic forest), and; 4) sub-montane to montane evergreen riparian forests (3 and 4 together, 7.1\%); 5) submontane to montane semi-deciduous seasonal forests on deep latosols (latosolic forests) $(6 \%)$; 6) transition zones $(7.3 \%)$; 7) wetlands $(0.7 \%) ; 8)$ alluvial sands $(0.5 \%)$, and; 9) anthropogenic landscapes $(1.6 \%)$. It should be noted that no areas of cerrado or caatinga exist within the current limits of the CDNP.

In spite of the fact that the Campo Rupestre (CR) vegetation experiences severe and extremely frequent burning cycles within the Sincorá Range (less than a decade in more protected areas, and almost annually in others) this vegetation form (as well as the related sedge meadows) has been able to greatly expand in this area as a result of anthropogenic disturbances. Mining allied with burning have eliminated the soil and the forest vegetation from enormous swathes of the Sincorá Range (on the order of $200 \mathrm{~km}^{2}$ ), and much of the landscape above $800 \mathrm{~m}$ has been occupied by $\mathrm{CR}$ vegetation (at lower altitudes, a transition vegetation with representatives of CR, cerrado, and invasive species).

There are basically two forms of sandy sedge meadows (M) found within the Sincorá Range (and the CDNP), but the important difference between them does not lie in their physiognomy or species composition, but rather in their origin.

The more original form of sandy sedge meadows grows on relatively flat landscapes in the mountains within the Sincorá Range on extremely thin, sandy, litholic neosols that are often saturated for fairly long periods of times during the rainy season. These sites have become more open and exposed, with less shrubs and small trees, due to extensive burning, but are otherwise truly natural sites.

The anthropogenic form of sandy sedge meadows now occupies the central axis of the Sincorá Range in an area of the CDNP dominated by a narrow anticlinal valley that stretches more than $53 \mathrm{~km}$ and averages over $900 \mathrm{~m}$ in altitude (Figure 2). The abundant rainfall and mist in the high mountains and the deep sandy sediments filling the valley floor favored dense forest formations in the past. However, constant and frequent anthropogenic fires, related principally to mining, agriculture, hunting, and native pasture management, have essentially eliminated the forest formations in this series of valleys, and the now open habitat was occupied principally by the fire-tolerant low-growing herbs and subshrubs of the original and neighboring sedge meadow vegetation.

Sub-montane to montane semi-deciduous season to evergreen forests on neosols (montane lithosolic forests) (F2) can be found throughout the Sincorá Range (Figures 2). Sub-montane semi-deciduous seasonal forests occupy the lower eastern facing slopes (starting at about $400 \mathrm{~m}$ a.s.1.) in exposed areas with sufficiently deep soils, as well as the sides of deep river valleys among boulders and rock outcrops. These forests, however, have been eliminated from huge areas on the slopes and within the valleys of the Serra do Sincorá due to both mining activities (which removes the soil) and fire, and these sites have been occupied by: 1) campo rupestre vegetation (following soil loss on mountains slopes above $800 \mathrm{~m}$ ); 2) transition vegetation composed of forest/shrubs and some elements of campo rupestre (following soil loss on the slopes below $800 \mathrm{~m}$ ); 3) sedge meadows, in high mountain valleys on deep sandy soils (due to the very high frequency of fires), or; 4) damaged forest (maintained in the earliest stages of growth and succession by repeated burning).

As the sub-montane lithosolic forests gain in altitude within the mountains there is a gradual alteration of the species composition, and they grade into a more evergreen physiognomy as environmental conditions become increasingly more humid. There are also more protected sites available in the mountains within deep valleys and crevices in the sandstone rock where very little mining activity was ever developed and the vegetation is sheltered from both drying and wildfires. These sites have a significant accumulation of damp organic material on the forest floor and are populated by species such as Podocarpus transiens (Plig.) deLaub., Hedyosmum brasiliensis Mart., Weinmannia paulliniaefolia Pohl ex Ser., and Drimys brasiliensis Miers (Funch 2008).

Large open valleys in the central portion of this range $(900 \mathrm{~m}$ and above) that were once densely forested have been extensively burned or cleared for farming (see section on sandy sedge meadows above), converting approx. $130 \mathrm{~km}^{2}$ of the montane lithosolic forest into open sedge meadows.

Sub-montane to montane evergreen riparian forests (F3) have been severely damaged and reduced within the entire Sincorá Range by mining, farming, and fire, and may be restricted to the width of just a few meters - although their importance as corridors for dispersal, especially for animals (Machtans et al. 1996, Spackman \& Hughes 1995) can be disproportional to their actual size. Important refuges from the damage being inflicted on this forest type can be found in the deep, narrow, and more protected valleys on the mid-slopes on the eastern side of the mountain range. No significant mining activity has ever been undertaken in those sites and the humidity in the narrow canyons protects the vegetation from wild fires.

Sub-montane semi-deciduous seasonal forests on deep latosols (latosolic forests) (F1) are found east of the Sincorá Range growing on deep latosols at altitudes from 400-600 m a.s.l. (Figure 2). Towards the west, the landscape becomes irregular and hilly, and the latosols terminate rather abruptly at the very foot of the mountains, except for some isolated "islands" of red clay soil almost invariably located on the rounded crests (usually between 600 and $800 \mathrm{~m}$ ) of the otherwise rocky and thin-soiled mountain slopes of the eastern flank of this range. The only intact forests now growing on latosol islands within the Sincorá Range are limited to areas on either side of the principal diamond mining zone (that is, north of the Mandassaia River, and south of the Piaba River). This central gap resulted from intensive mining activities in the late $19^{\text {th }}$ and early $20^{\text {th }}$ century that left behind only scattered remnant scraps of intact soil (and forest). But even the latosol forest 
islands outside of the mining zone are at least as heavily damaged as the lowland tableland forests (for they are not only damaged through agricultural practices but are also surrounded by drier mountain vegetation that experiences more frequent wildfires).

As such, the once continuous forest that blanketed all of the area east of the Sincorá Range, as well as portions of its flanks, has now been replaced by a tattered and discontinuous fabric of pillaged patches as a consequence of selective logging, burning, and clearing for farming or pasture formation (usually involving the production of charcoal after the more commercially valuable wood has been cut for lumber). Even what appears on satellite images to be a more compact forest block to the NE of the National Park is, for the most part, a heavily fire-damaged early successional forest.

While spontaneous (natural) fires almost certainly can occur in the Chapada Diamantina, an overwhelming percentage of wildfires are anthropogenic and related to escaped burns intended to clear lands for pasture/agricultural transformation (or renovation), or to scorch native savannas and grass lands to improve grazing conditions (these uncontrolled fires can then spread to other vegetation formations), as well as to hunting (either to drive game, improve their "pasture", or remove cover). Criminal or accidental burning are also very common on otherwise unoccupied lands.

Nonetheless, the best preserved sections of sub-montane semideciduous seasonal forests on deep latosols are nestled right against the slopes of the Sincorá Range where both rainfall and humidity tend to be greater and the steep terrain presents less favorable conditions for agricultural/pastoral invasion, harvesting, mining, and wildfires.

Transition/Mosaic vegetation (T) forms are extremely common in the mapping region Figure 2), as would be expected in an area with a mountainous landscape and that has been subjected to severe anthropogenic alterations.

Cerrado (C) vegetation dominates a rather distinct sector in the west-central to south-western region of the study area (approx. $1600 \mathrm{~km}^{2}$ ). It can be readily seen in the field, as well as on the satellite images (Figure 2), that the cerrado zone in the mapping area is divided into two principal geomorphological areas. In the smaller, very northern sector the landscape is deeply dissected and more heavily occupied for traditional (manual) agricultural uses, due to the greater density of permanent water courses in these deep valleys and their generally more humid conditions. The bulk of the cerrado zone, however, is a generally gently rolling landscape of extremely deep soils that range from sandy argisols to white, yellow, or (more rarely) red clays (latosols), and it is dominated by more open forms of cerrado (campo sujo, campo cerrado), with more arboreal forms (cerradão) occupying only depressions/drainage courses. Some of the typical cerrado species in this area include Anacardium humile Mart., Annona coriacea Mart., Duguetia furfuracea R.E.Fr., Croton campestris A.St.-Hil., Axonopus sp., and Hancornia speciosa Gomes. Intensive mechanized agricultural use of these lands initiated in the late 1970's, and significant areas have cleared and are currently under cultivation (especially using central pivot irrigation techniques). Nonetheless, this region has the highest percentage (approx. 35\%) of intact landscapes within the study area (lands that have not been mechanically disturbed, but only used for grazing).

Caatinga (caat) vegetation is encountered only in the northwestern mapping sector of this study (Figure 2) although it is by far the dominant vegetation type in the entire region to the west of the study area. Almost all of this caatinga vegetation has been severely modified by anthropogenic processes - principally intensive cattle grazing. The seasonal droughts force the cattle to scavenge widely and intensively for forage, and the generally flat to rolling landscape facilitates their movement. As a result, very few areas have escaped this intensive use. Interestingly, wildfires do not seem to be a sig- nificant factor in determining the conservation status of the caatinga vegetation, in spite of the extreme dryness of this region. Whether this is due to a more careful control of fire by local residents or some natural tendency of the regional caatinga vegetation there to poorly propagate combustion is not known.

\section{Discussion}

One of the primary goals of the vegetation map presented here was to aid in regional planning, management, and conservation. As such, well-known and well-defined Brazilian ecosystem names were used (e.g. campo rupestre, caatinga, cerrado) to facilitate the understanding and use of the document, and, due to the complexity of the landscape, some ecological systems were also mapped (e.g. alluvial sands, wetlands, anthropogenic regions), while in yet other cases edaphic distinctions were made between otherwise physiognomically almost indistinguishable forest types (Sub-montane to montane semi-deciduous seasonal forests on deep latosols [F1] and Sub-montane to montane semi-deciduous seasonal to evergreen forests on litholic neosols [F2]), or large-scale disturbance regimes (burning) were found to determine apparently very similar open meadow physiognomies (M1 and M2 sandy sedge meadows) derived from totally distinct original forms.

The distinction between these two above mentioned forest types came to light during the field work phase of this project, originally due to the notable lack of certain species (e.g. Eschweilera tetrapetala Mori) in the montane areas of the Sincorá Range. While some of the species differences may be related to anthropogenic factors (selective harvesting, etc.), the mapping and identification of the F2 forests growing on thin sandy soils will have very relevant management and conservation importance as these areas have less water-retention properties and are therefore generally drier during the dry season and subject to more frequent and intense burning. These F2 forests apparently occupied most of the litholic neosols covering the eastern flanks of the Sincorá Range that are currently occupied by transition (T1) and campo rupestre vegetation but were reduced to their current restricted distribution due to mining (erosion) and, principally, anthropogenic burning (R.R. Funch, unpublished data).

Additionally, the resources available for digitalized mapping facilitates the inclusion of almost limitless types of data in different digital map "layers", such as soil types, underlying geology, temperature and rainfall isoclines, species/collections localities, conservation status, etc., some of which are included in the map presented here (Figure 2).

\section{Conservation Considerations Derived from the Mapping}

The CDNP constitutes the core area of the present mapping region and occupies almost exclusively the highlands of the Sincorá Range. An analysis of the vegetation within and surrounding the reserve, and the degree of conservation (and human occupation) of the areas contiguous with its legal limits, identified a number of areas that should be annexed to the Park and that would significantly increase its effectiveness as a conservation area as well as help guarantee its ecological sustainability. These results, and other recommendations for conservation actions within the Park, have been presented in much more detail as a separate publication (Funch \& Harley 2007).

The Chapada Diamantina falls within the zone of hypoxerophilous vegetation (Queiroz et al. 2005), with caatinga dry land vegetation being the predominant vegetation cover in the mountain range as a whole. There are ca. $30 \mathrm{~km}^{2}$ of very well preserved caatinga vegetation zones contiguous to the NW sector of the CDNP. These sites appear to have remained largely intact due to steep terrain and shallow neosols that preclude their use either for natural pasture or for farming. For these same reasons, these lands have little commer- 
cial value and could be acquired at very low cost (if they are not, in fact, unclaimed state lands). As such, it is highly recommended that these areas be seriously considered for conservation/preservation. Due to their relatively reduced size and location they could easily be incorporated into the neighboring state-administered Environmental Protection Area or acquired by the state and converted into reserves under more rigorous protection regimes.

Although almost the entire area west of the Chapada Diamantina National Park is dominated by cerrado vegetation, it presently has no representation within the limits of the reserve (Figure 2). Its exclusion from the Park was the result of to two basic factors: 1) the cerrado is located outside of the Sincorá Range and is separated from it by a natural barrier (an impressive fault scarp approximately $250 \mathrm{~m}$ tall, running for more than $70 \mathrm{~km}$ in a N-S alignment) that was chosen to define the western limit of the reserve as well as man-made features (such as roads) that were considered inappropriate for inclusion within the reserve; 2 ) the cerrado region, especially those areas nearest to the fault scarp with their convenient water resources and deep soils, is almost entirely occupied by small farms and villages.

As there are no other public conservation areas in the region, not a single part of this regional cerrado vegetation enjoys any specific legal protection. Brazilian law, however, does require private owners to set aside and preserve at least $20 \%$ of their land holdings (being free to use the other $80 \%$ for agricultural purposes). As most of this high plain is in the possession of large land owners, the most viable solution would seem to be to organize these landowners to preserve plots that are (to the maximum degree possible) contiguous. This effort would provide for a extremely large conservation area at no addition cost to the government (besides the work involved in routine monitoring, which could be easily done using satellite images), create corridors of dispersal and communication throughout the plateau, and insure a uniform representation of the region (cerrado vegetation generally does not demonstrate point sources of endemism as does, for example, campo rupestre, so that larger areas are needed to capture vegetation changes).

As such, in addition to its value as a park planning tool, the vegetation map presented here suggests a number of well preserved areas that could be incorporated into existing conservation areas (or made into their own reserves) without competing with local communities, and with minimum economic costs to them or to the government agencies involved.

\section{Acknowledgements}

We thank the Brazilian Parks Dept. (IBAMA) for their help during parts of this survey in the Chapada Diamantina National Park, the anonymous reviewers who supplied many valuable suggestions to refine this paper; as well as Miro, Silvo, Walter, Vadinho, and many other woodsmen who accompanied us during the plant surveys.

\section{References}

Companhia de Pesquisa de Recursos Minerais - CPRM. 1994. Parque Nacional da Chapada Diamantina - BA. Informações básicas para a gestão territorial: diagnóstico do meio físico e da vegetação. CPRM; IBAMA, Salvador.

FUNCH, L.S. 2008. Florestas da região norte do Parque Nacional da Chapada Diamantina e seu entorno. In Serra do Sincorá - Parque Nacional da Chapada Diamantina (L.S. Funch, R.R. Funch \& L.P. Queiroz, orgs.). Radami Editora Gráfica, Feira de Santana, p. 63-78.

FUNCH, L.S., BARROSO, G.M. \& FUNCH, R.R. 2002. Phenology of Riparian and Montane Forest in the Chapada Diamantina, Bahia, Brazil. Biotropica, 34(1):40-50.

FUNCH, L.S., FUNCH, R.R., HARLEY, R., GIULIETTI, A.M., QUEIROZ, L.P., FRANÇA, F., MELO, E., GONÇALVES, C.N. \& DANTOS, T. 2005. Florestas estacionais semideciduais. In Biodiversidade e conservação da
Chapada Diamantina (F.A. Junca, L. Funch \& R. Rocha, orgs.). Ministério do Meio Ambiente, Brasília, p. 181-193.

FUNCH, R.R. \& HARLEY, R.M. 2007. Reconfiguring the boundaries of the Chapada Diamantina National Park (Brazil) using ecological criteria in the context of a human-dominated landscape. Landsc. urban plan. 83(4):355-362.

HARLEY, R.M. 1995. Introduction. In Flora of the Pico das Almas, Chapada Diamantina, Brazil (B.L. Stannard, ed.). Royal Botanic Gardens, Kew, p. 23-62.

HARLEY, R.M. \& SIMMONS, N.A. 1986. Florula of Mucugê, Chapada Diamantina, Bahia, Brazil. Royal Botanic Gardens, Kew.

HARLEY, R.M., GIULIETTTI, A.M., GRILO, A.S., SILVA, T.R.S., FUNCH, L., FUNCH, R.R., QUEIROZ, L.P., FRANÇA, F., Melo, E., GONÇALVES, C.N. \& NASCIMENTO, F.H.F. 2005. Cerrado. In Biodiversidade e conservação da Chapada Diamantina (F.A. Junca, L. Funch \& R. Rocha, orgs.). Ministério do Meio Ambiente, Brasília, p. 121-152.

JESUS, E.F.R., FALK, F.H., RIBEIRO, L.P. \& MARQUES, T.M. 1985. Caracterização geográfica e aspectos geológicos da Chapada Diamantina - Bahia. Universidade Federal da Bahia, Bahia.

KINGSTON, N. \& WALDREN, S. 2003. The plant communities and environmental gradients of Pitcairn Island: the significance of invasive species and the need for conservation management. Ann. Bot. 92(1):31-40.

MACHTANS, C.S., VILLARD, M. \& HANNON, S.J. 1996. Use of riparian buffer strips as movement corridors by forest birds. Conserv. biol. 10:1366-1379.

NOLASCO, M.C., LIMA, C.C.U., FRANCA-ROCHA, W. \& RÊGO, M.J.M. 2008. Aspectos físicos da Serra do Sincrá Chapada Diamantina (Bahia). In Serra do Sincorá - Parque Nacional da Chapada Diamantina (L.S. Funch, R.R. Funch \& L.P. Queiroz, orgs.). Radami Editora Gráfica, Feira de Santana, p. 17-34.

PIVELLO, V.R., CARVALHO, V.M.C., LOPES, P.F., PECCININI, A.A. \& ROSSO, S. 1999. Abundance and distribution of native and invasive alien grasses in a “cerrado' (Brazilian savanna) biological reserve. Biotropica, 31(1):71-82.

QUEIROZ, L.P., FRANÇA, F., GIULIETTI, A.M., MELO, F., GONÇALVES, C.N., FUNCH, L.S., HARLEY, R.M., FUNCH, R.R. \& SILVA, T.S. 2005. Caatinga. In Biodiversidade e conservação da Chapada Diamantina (F.A. Junca, L. Funch \& R. Rocha, orgs.). Ministério do Meio Ambiente, Brasília, p. 95-120.

ROCHA, P.L.B., QUEIROZ L.P. \& PIRANI, J.R. 2004. Plant species and habitat structure in a sand dune field in the Brazilian Caatinga: a homogeneous habitat harboring an endemic biota. Rev. Bras. Bot. 27(4):739-755

ROCHA, W.J.S.F., CHAVES, J.M., ROCHA, C.C. \& LOBÃO, J.B. 2005. Unidades de Paisagem da Chapada Diamantina. In Biodiversidade e conservação da Chapada Diamantina (F.A. Junca, L. Funch \& R. Rocha, orgs.). Ministério do Meio Ambiente, Brasília, p. 47-64.

SAYRE, R., ROCA, E., SEDAGHATKISH, G., YOUNG, B., KEEL, S., ROCA, R. \& SHEPPARD, S. 2000. Nature in focus: rapid ecological assessment. Island Press, Washington, D.C.

SEIXAS, B.L.S. 2004. Água: usos, características e potencialidades. Nova Civilização, Cruz das Almas, Bahia.

SOUZA, V.C. \& LORENZI, H. 2005. Botânica Sistemática: guia ilustrado para identificação das famílias de angiospermas da flora brasileira, baseado em APG II. Instituto Plantarum, Nova Odessa, São Paulo.

SPACKMAN, S.C. \& HUGHES, J.W. 1995. Assessment of minimum stream corridor width for biological conservation: species richness and distribution along mid-order streams in Vermont, USA. Bio. Conserv. 71:325-332

Superintendência do Desenvolvimento do Nordeste-SUDENE. 1977. Região Nordeste do Brasil - 1:100.000. Ministério do Interior, Brasília, DF.

Data Received 10/03/08 Revised 10/12/08 Accepted 01/04/09 